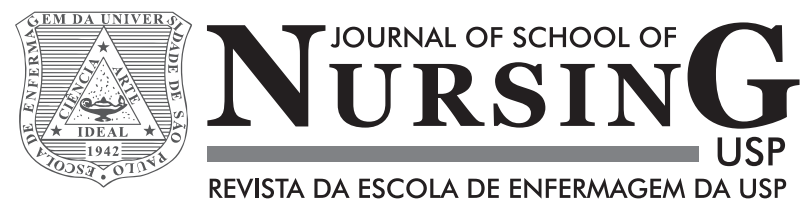

\title{
Development of the short version of the Informal Caregiver Burden Assessment Questionnaire
}

\author{
Desenvolvimento de uma versão reduzida do Questionário De \\ Avaliação Da Sobrecarga do Cuidador Informal \\ Desarrollo de una versión reducida del Cuestionario de \\ Evaluación de la Sobrecarga del Cuidador Informal
}

Teresa Martins ${ }^{1}$, Maria José Peixotoㄹ, Fátima Araújo² ${ }^{2}$, Marta Rodrigues ${ }^{3}$, Fátima Pires ${ }^{4}$

${ }^{1}$ Coordinating Professor, Escola Superior de Enfermagem do Porto, Oporto, Portugal.

${ }^{2}$ Assistant Professor, Escola Superior de Enfermagem do Porto, Oporto, Portugal.

${ }^{3}$ Master of Community Nursing, Local Health Unit of Matosinhos, Oporto, Portugal.

${ }^{4}$ Nurse Specialising in Rehabilitation Nursing, Hospital Centre of Oporto, Oporto, Portugal.

\begin{abstract}
Objetive: to create a reduced version of the QASCI, which is structurally equivalent to the long one and meets the criteria of reliability and validity. Method: Through secondary data from previous studies, the participants were divided into two samples, one for the development of reduced version and the second for study of the factorial validity. Participants responded to QASCI, the SF 36, the ADHS and demographic questions. Results: A reduced version of 14 items showed adequate psychometric properties of validity and internal consistency, adapted to a heptadimensional structure that assesses positive and negative aspects of care. Conclusion: Confirmatory factor analysis revealed a good fit with the advocated theoretical model.
\end{abstract}

DESCRIPTORS

Caregivers; Family; Validation Studies; Psychometrics. 


\section{INTRODUCTION}

Burden has been used to designate physical, emotional, social and financial problems experienced by family caregivers (FC) for dependent adults ${ }^{(1)}$. The caregiver burden described as a perturbation results from dealing with the physical dependency and mental incapacity of the individual who is a target of the attention and care and corresponds to the subjective perception of threats relating to the physiological, social and psychological needs of the caregiver ${ }^{(1)}$. In this way, it is seen as a result of the evaluation by caregivers of their social role, the tasks which they carry out, the perception and development of the disease and the interferences which these factors cause in the various areas of their lives.

The Informal Caregiver Burden Assessment Questionnaire (QASCI) was developed to give a reply to the need to evaluate the medium and long-term consequences of performance of this role on the well-being of caregivers of persons after a cerebrovascular accident $(\mathrm{CVA})^{(2)}$. The authors replicated the study on family caregivers of persons with pathologies other than CVA, having obtained identical results regarding their psychometric properties and dimensions $^{(3)}$. The instrument was used, above all for the investigation aspect and was well accepted by participants, as were criteria of validity and fidelity ${ }^{(1-3)}$. However, in providing care, it is desirable to have more concise instruments which take less time to complete ${ }^{(4-7)}$.

This study aims to create a Short Version of the QASCI, which is structurally equivalent to the long one and which includes the criteria of fidelity and validity.

\section{METHOD}

A descriptive study was completed on the basis of the secondary analysis of the data of three prospective studies with family caregivers of persons with a self-care deficit. The primary studies met with the approval of the ethics committees of the involved institutions (HSA:118/CES/06; ULSM:2010/CES/07; HSJ: 50/CES/00) and took nonprobabilistic samples as a basis (convenience).

For this study, participants were allocated at random into two samples. After the elimination of those who did not complete the relevant questionnaire, the first sample presented an $\mathrm{n}=455$ and the second, 419 . The data from the first sample were used to develop the short version and those of the second, to test the theoretical model through confirmatory factor analysis (AFC).

The criteria for the inclusion of individual in the study were: 1) being the principal person responsible for providing care and assisting with the daily activities of a dependent relative or friend; 2) the subject who was the target of healthcare had to have been in a situation of functional dependence for at least six months, in at least one basic activity of daily life (BADL) or two instrumental activities of daily life (IADL); 3) the caregivers necessarily had to have had contact with a person who was the object of care during the last four weeks. Participants were recruited with the collaboration of health centers of a Local Health Unit and of two general hospitals of the Greater Oporto region.
Among the family caregivers, $87.5 \%$ were female. The average age was 57.68 years $(\mathrm{DP}=13.36)$, varying from 20 to 88 years, with $52.1 \%$ aged between 46 and 65 years and $9.9 \%$ over 86 . The majority were married $(86.6 \%)$ and retired (49.0\%). Only $29.4 \%$ continued working after the situation of the illness/dependency of the relative. On average they had completed 4.98 years of schooling $(\mathrm{DP}=3.99)$. The vast majority (85.1\%) lived in the same residence as the dependent person and $57.5 \%$ received some type of assistance with the provision of care, spending an average of 13.8 hours per day on caring $(\mathrm{DP}=8.95)$. With regard to the degree of kinship with the person forming the object of the care, $41.1 \%$ were spouses and $38.5 \%$ children. The vast majority considered that they had a good or very good emotional relationship with the dependent person. We highlight that $30.2 \%$ were responsible for more than one dependent person. In more than half of the situations (54.6\%), the relative with a self-care deficit could remain at home alone for a period exceeding 4 hours and $55.2 \%$ considered the relative to be in a poor state of health.

In addition to the sociodemographic variables, data were analyzed on the evaluation of the state of health, anxiety, depression and burden relating to caring. The state of health and quality of life were evaluated via SF $36^{(8)}$, a scale consisting of 36 items integrated into 8 subscales: Physical functioning (10 items), Physical performance (4 items), Emotional performance (3 items), Bodily pain (2 items), Mental health (5 items), Social functioning (2 items), Vitality (4 items) and General health (5 items); in addition to one item which quantifies changes of health occurring over the last year.

Anxiety and depression were evaluated by the Hospital Anxiety and Depression Scale $(\mathrm{EADH})^{(9)}$, consisting of 14 items. The total values on each subscale exceeding 8 and less than 10 require evaluation to confirm a depressive state, while values exceeding 11 require intervention and monitoring ${ }^{(9)}$.

Physical, emotional and social burden was evaluated by the $\mathrm{QASCI}^{(2)}$, with 32 items and 7 dimensions: Impact on Personal Life of the caregiver (11 items); Satisfaction with role and with the relative (5 items); Reactions to Demands (5 items); Emotional Burden (4 items); Family Support (2 items); Financial Burden (2 items) and Perception of mechanisms of efficacy and control (3 items). In calculating the scores for each dimension, a formula was applied for each dimension varying from 0 to $100^{(1)}$.

A set of criteria was chosen for the construction of the short version ${ }^{(10-14)}$. In this way, an item would be eliminated if more than $5 \%$ of replies were omitted ${ }^{(5)}$; correlation between items $\geq 0,70^{(5,13)}$; factor load $<0,40^{(11,13)}$; if they did not present discriminating power ${ }^{(7)}$ and did not contribute to the internal consistency of the subscale ${ }^{(4)}$. After the application of these criteria, two items would be selected with a greater factor load, a procedure used in other studies ${ }^{(12,15)}$. If items with equal weight were registered in the application of these criteria, the decision of choice fell on a panel of experts, constituted by investigators in the scientific field.

For the statistical treatment of the data, the IBM SPSS version 22.0 program was used, with use made of paramet- 
ric and multivariate statistics. The fidelity of the subscales was evaluated via Cronbach's alpha coefficient, which provides the measure of internal consistency of the scale. Use was made of Pearson's correlation in order to evaluate the strength of association between continuous variables. In order to analyses the differences in means between two independent continuous variables, Student's $t$ test was used. Exploratory factor analysis was carried out through Principal Component Analysis, with recourse to orthogonal rotation according to the Varimax method. The adjustment of data for the use of this analysis was verified via the KaiserMeyer-Olkin (KMO) criteria and by Bartlett's test. The following criteria were followed for confirming the number of factors: 1) eigenvalue $>1 ; 2$ ) exclusion of factor loads $<0.40$; 3 ) each factor had to explain a minimum of $5 \%$ of variance and 4) application of discontinuity principles.

Factor validity was evaluated via AFC with recourse to AMOS. The existence of outliers was evaluated by the Mahalonobis distance and normality via the asymmetry coefficient and uni-and multivariate kurtosis. The covariance matrix was considered as an input, with the adoption of the Maximum Likelihood Method for estimation.

The quality of the adjustment of the model was carried out in accordance with the indices, observing reference values ${ }^{(10,16)}$. The local adjustment was evaluated by the factor weights and by the individual reliability of the items. We consider the Goodness-of-fit index (GFI) and the
Adjusted goodness-of-fit index (AGFI), the Comparative Fit Index (CFI) and finally the Root Mean Square Error Approximation (RMSEA). The GFI, AGFI and CFI must lie close to 0.90 , while the recommended RMSEA ranges up to $0.08^{(10,16)}$. In addition to the modification indices, the adjustment of the model took account of the theoretical considerations.

\section{RESULTS}

The results of the exploratory factor analysis (Table 1) show that in the allocation of the factors to the components (values in bold), the vast majority overlap with the allocation proposed by the authors (grey shading). 4 of the 11 items which should have been allocated to the Impact on Personal Life of the caregiver dimension were diverted to the Emotional Burden dimension. Items 4, 7, 15, 22, and 28 did not present any discrimination power and were eliminated.

The items with more omitted responses correspond to questions which evaluate the reply and responsiveness of the patient (Response to demands dimension) and satisfaction with role and with the relative, albeit without reaching 5\% of omitted responses. A tendency was found for replies to cluster around the less extreme options, without a ceiling or floor effect for almost all of the items. No item was found with an inter-item correlation $\geq 0.70$. The application of the criterion "non-contribution to internal consistency of the subscale" lead to the elimination of items 22 and 25.

Table 1 - Factor loads of exploratory factor analysis - Portugal, 2104

\begin{tabular}{|c|c|c|c|c|c|c|c|}
\hline & \multicolumn{7}{|c|}{ Components } \\
\hline & 1 & 2 & 3 & 4 & 5 & 6 & 7 \\
\hline 1-Desire to flee from the situation & 0.50 & 0.31 & 0.11 & 0.13 & 0.30 & 0.10 & 0.06 \\
\hline 2-Psychologically difficult & 0.70 & 0.22 & 0.18 & 0.03 & 0.06 & -0.02 & -0.09 \\
\hline 3-Feeling tired and exhausted & 0.77 & 0.16 & 0.03 & -0.01 & 0.14 & 0.09 & 0.13 \\
\hline 4-Self conflict* & 0.40 & 0.48 & 0.20 & 0.08 & 0.27 & 0.05 & 0.02 \\
\hline 5 -Deterioration in health & 0.65 & 0.11 & 0.25 & 0.01 & 0.24 & 0.19 & 0.07 \\
\hline 6-Care has required a physical effort & 0.69 & 0.08 & 0.22 & -0.15 & 0.01 & 0.20 & -0.00 \\
\hline 7-Loss of control* & 0.48 & 0.13 & 0.41 & -0.03 & 0.22 & 0.27 & 0.05 \\
\hline 8-Altered plans & 0.39 & 0.11 & 0.64 & 0.01 & 0.03 & 0.19 & -0.07 \\
\hline 9-Not enough time for oneself & 0.60 & 0.11 & 0.37 & 0.08 & 0.03 & 0.11 & -0.04 \\
\hline 10-Feeling that life has played a dirty trick & 0.35 & 0.09 & 0.46 & 0.26 & -0.10 & 0.27 & 0.02 \\
\hline 11-Difficult to plan for the future & 0.38 & 0.00 & 0.52 & -0.10 & -0.06 & 0.18 & 0.06 \\
\hline 12-Feeling trapped & 0.61 & 0.21 & 0.33 & -0.00 & 0.07 & -0.13 & -0.02 \\
\hline 13-Avoiding inviting friends & 0.11 & 0.20 & 0.64 & 0.02 & 0.26 & 0.02 & 0.07 \\
\hline 14-Social life impaired & 0.30 & 0.03 & 0.73 & -0.00 & -0.08 & -0.05 & -0.03 \\
\hline 15 -Feeling alone and isolated* & 0.47 & 0.17 & 0.46 & 0.07 & 0.14 & 0.13 & 0.08 \\
\hline 16-Experiencing economic difficulties & 0.17 & 0.10 & 0.14 & -0.03 & 0.10 & 0.85 & 0.08 \\
\hline 17-Uncertain economic future & 0.19 & 0.10 & 0.11 & -0.10 & 0.03 & 0.84 & 0.04 \\
\hline 18-Feeling offended & 0.26 & 0.73 & 0.03 & 0.20 & 0.09 & 0.03 & 0.02 \\
\hline 19-Feeling embarrassed & 0.20 & 0.71 & 0.09 & 0.20 & 0.02 & 0.04 & -0.02 \\
\hline 20-Excessive requests & 0.12 & 0.68 & 0.08 & -0.07 & 0.05 & 0.12 & 0.02 \\
\hline 21-Feeling manipulated & 0.12 & 0.76 & 0.14 & 0.07 & 0.21 & 0.05 & 0.02 \\
\hline 22-Reduction in privacy* & 0.08 & 0.44 & 0.44 & -0.25 & 0.31 & -0.03 & 0.04 \\
\hline
\end{tabular}




\begin{tabular}{|c|c|c|c|c|c|c|c|}
\hline & \multicolumn{7}{|c|}{ Components } \\
\hline & 1 & 2 & 3 & 4 & 5 & 6 & 7 \\
\hline 23-Succeeding in doing the majority of things & 0.22 & -0.01 & 0.09 & 0.05 & 0.68 & 0.06 & 0.10 \\
\hline 24-Capacity to go on & 0.31 & 0.12 & 0.04 & 0.21 & 0.70 & -0.08 & 0.17 \\
\hline 25-Gaining knowledge or experience & -0.02 & 0.16 & -0.02 & -0.07 & 0.62 & 0.11 & -0.03 \\
\hline 26-Recognition by the family & -0.01 & -0.03 & -0.01 & 0.12 & 0.16 & -0.01 & 0.87 \\
\hline 27-Support by the family & 0.06 & 0.07 & 0.05 & 0.10 & 0.00 & 0.13 & 0.88 \\
\hline 28-Feeling well* & 0.11 & 0.24 & 0.11 & 0.48 & 0.47 & -0.02 & -0.05 \\
\hline 29-Relative demonstrates gratitude & 0.06 & 0.20 & 0.22 & 0.61 & -0.12 & -0.16 & 0.24 \\
\hline 30-Recognition of work & -0.04 & 0.26 & 0.00 & 0.64 & 0.21 & 0.10 & -0.07 \\
\hline 31-Feeling closer & -0.06 & 0.01 & -0.16 & 0.73 & 0.06 & 0.08 & 0.06 \\
\hline 32-Increased self-esteem & 0.02 & -0.09 & 0.01 & 0.64 & -0.03 & -0.19 & 0.11 \\
\hline
\end{tabular}

* item without discrimination power

Legend: SE - Emotional Burden; IVP - Impact on Personal Life; SF - Financial Burden; RE - Reactions to Demands; PMEC - Perception of Efficacy and Control Mechanisms; SupF - Family Support; SPF - Satisfaction with role and with the relative.

After the application of the preceding criteria for the reduction of items, we moved on to the choice of two items with the highest factor load, which had not been previously excluded. In selecting the second item of the dimensions Impact on the personal life of the caregiver and Satisfaction with role and with the relative, two items were found with an equal factor load and the choice was made by the group of experts through the qualitative analysis of its content.

In view of the final solution encountered, a new analysis was undertaken of the principal components with the 14 selected items. The factor solution encountered explained $72 \%$ of the overload values and suggested 6 components, aggregating the Impact on Personal Life and Emotional Burden dimensions into a single dimension with 4 items. The separation of these two dimensions nevertheless made sense from a theoretical perspective (Appendix 1).

The internal consistency values of the Short Version (QASCI-VR) presented in Table 2 are indicative of acceptable to good internal consistency, despite presenting values below those of the long version. Only the Satisfaction with role and with the relative dimension showed a low value, albeit which was very close to the reference value. The internal consistency of the total scale was 0.71 .

Table 2 - Cronbach's alpha coefficients of the QASCI and QASCI-VR subscales - Portugal, 2014

\begin{tabular}{lcc}
\hline & QASCI & QASCI-VR \\
\hline Emotional Burden & 0.77 & 0.66 \\
Impact on Personal Life & 0.80 & 0.70 \\
Financial Burden & 0.82 & 0.82 \\
Reactions to Demands & 0.77 & 0.67 \\
Perception of Effective Control & 0.61 & 0.67 \\
Mechanisms & 0.77 & 0.77 \\
Family Support & 0.68 & 0.59 \\
\hline Satisfaction with Role and Relative & & \\
\hline
\end{tabular}

The correlation value between the Short Version and the long one was 0.95 , indicating redundancy and superposition of results. The analysis of the correlation of the same dimension between the Short Version and the long one was 0.81 for the Impact on Personal Life and for Family Support. The remaining dimensions which suffered alterations presented values between 0.89 and 0.90 . In general, the items selected for a Short Version showed a stronger correlation with the QASCI-VR than with the long version (Table 3).

Table 3 - Means and standard deviations of each item, dimension to which they belong and correlation with a total scale in the long and reduced versions - Portugal, 2104

\begin{tabular}{|c|c|c|c|c|c|}
\hline & \multicolumn{5}{|c|}{ Correlation } \\
\hline & $M$ & DP & Dimension & QASCI & QASCI-VR \\
\hline $\begin{array}{l}\text { 2-Psychologically } \\
\text { difficult }\end{array}$ & 3.18 & 1.32 & SE & 0.51 & 0.53 \\
\hline $\begin{array}{l}\text { 3-Feeling tired } \\
\text { and exhausted }\end{array}$ & 3.16 & 1.24 & SE & 0.59 & 0.59 \\
\hline 8-Altered plans & 3.58 & 1.50 & IVP & 0.49 & 0.56 \\
\hline $\begin{array}{l}\text { 14-Social life } \\
\text { impaired }\end{array}$ & 3.57 & 1.48 & IVP & 0.34 & 0.46 \\
\hline $\begin{array}{l}\text { 16-Experiencing } \\
\text { economic } \\
\text { difficulties }\end{array}$ & 2.42 & 1.45 & SF & 0.55 & 0.50 \\
\hline $\begin{array}{l}\text { 17-Uncertain } \\
\text { economic future }\end{array}$ & 2.44 & 1.50 & SF & 0.50 & 0.47 \\
\hline $\begin{array}{l}\text { 18-Feeling } \\
\text { offended }\end{array}$ & 2.31 & 1.16 & RE & 0.50 & 0.49 \\
\hline $\begin{array}{l}\text { 21-Feeling } \\
\text { manipulated }\end{array}$ & 2.07 & 1.27 & RE & 0.53 & 0.50 \\
\hline $\begin{array}{l}\text { 23-Succeeding } \\
\text { in doing the } \\
\text { majority of } \\
\text { things* }\end{array}$ & 2.39 & 1.21 & PMEC & 0.46 & 0.47 \\
\hline $\begin{array}{l}\text { 24-Capacity to } \\
\text { go on* }\end{array}$ & 2.13 & 1.16 & PMEC & 0.56 & 0.54 \\
\hline $\begin{array}{l}26-\text { Recognition } \\
\text { by the family* }\end{array}$ & 2.45 & 1.54 & SupF & 0.41 & 0.41 \\
\hline $\begin{array}{l}\text { 27- Support by } \\
\text { the family* }\end{array}$ & 2.64 & 1.52 & SupF & 0.48 & 0.46 \\
\hline $\begin{array}{l}\text { 31- Feeling } \\
\text { closer...* }\end{array}$ & 1.96 & 1.38 & SPF & 0.18 & 0.28 \\
\hline $\begin{array}{l}32 \text { - Increased } \\
\text { self-esteem * }\end{array}$ & 2.69 & 1.53 & SPF & 0.13 & 0.25 \\
\hline
\end{tabular}

Legend: SE- Emotional Burden; IVP- Impact on Personal Life; SFFinancial Burden; RE- Reactions to Demands; PMEC- Perception of Efficacy and Control Mechanisms; SupF- Family Support; SPFSatisfaction with role and with the relative 
The divergent validity was studied by comparing the correlation matrix of the QASCI and QASCI-VR with the subscales of the SF 36 (table 4 and 5), starting from the hypothesis of a negative association of these constructs. The correlation pattern encountered between the QASCI-VR and the SF 36 was superimposable on the pattern encountered between the long version and the SF 36, for the majority of the dimensions. The results showed that a larger burden was associated with worse quality of life. Participants with a greater burden associated with the provision of care had more impaired mental health, less vitality, worse social functioning and a more precarious general perception of health. The convergent study of validity was carried out with recourse to the EADH (Tables 4 and 5). The pattern of correlations found was very similar in the long and short versions, revealing a positive moderate to strong association between these measures, indicating that the caregivers with greater overload are more vulnerable and susceptible to developing depression.

Table 4 - Correlations of the dimensions of the SF 36 and of the EADH with the dimensions of the QASCI - Portugal, 2104

\begin{tabular}{|c|c|c|c|c|c|c|c|c|}
\hline & SE & IVP & SF & RE & PMEC & SupF & SPF & QASCI \\
\hline \multicolumn{9}{|c|}{ SF 36} \\
\hline FF & $-0.22^{* *}$ & $-0.22^{* *}$ & $-0.24^{* *}$ & -0.07 & $-0.26^{* *}$ & $-0.10^{*}$ & $-0.10 *$ & $-0.29 * *$ \\
\hline DF & $-0.37^{* *}$ & $-0.37^{* *}$ & $-0.27^{* *}$ & $-0.28^{* *}$ & $-0.36^{* *}$ & $-0.10^{*}$ & $0.10^{*}$ & $-0.39 * *$ \\
\hline $\mathrm{DE}$ & $-0.28^{* *}$ & $-0.29 * *$ & $-0.21^{* *}$ & $-0.24^{* *}$ & $-0.24^{* *}$ & -0.03 & 0.09 & $-0.27^{* *}$ \\
\hline Vita & $-0.36^{* *}$ & $-0.41^{* *}$ & $-0.24^{* *}$ & $-0.17^{* *}$ & $-0.29 * *$ & $-0.24^{* *}$ & $-0.22^{* *}$ & $-0.46^{* *}$ \\
\hline $\mathrm{FS}$ & $-0.43^{* *}$ & $-0.44^{* *}$ & $-0.27^{* *}$ & $-0.41^{* *}$ & $-0.43^{* *}$ & $-0.11^{*}$ & 0.01 & $-0.47^{* *}$ \\
\hline SM & $-0.43^{* *}$ & $-0.50^{* *}$ & $-0.28^{* *}$ & $-0.33^{* *}$ & $-0.27^{* *}$ & $-0.16^{* *}$ & $-0.18^{* *}$ & $-0.51^{* *}$ \\
\hline Pain & $-0.30^{* *}$ & $-0.34^{* *}$ & $-0.30^{* *}$ & $-0.13^{* *}$ & $-0.12^{*}$ & -0.06 & -0.01 & $-0.30^{* *}$ \\
\hline \multicolumn{9}{|c|}{ EADH } \\
\hline EA & $0.51^{* *}$ & $0.49 * *$ & $0.31^{* *}$ & $0.34^{* *}$ & $0.31^{* *}$ & $0.22^{* *}$ & $0.14^{*}$ & $0.54^{* *}$ \\
\hline ED & $0.48^{* *}$ & $0.51^{* *}$ & $0.28^{* *}$ & $0.26^{* *}$ & $0.38^{* *}$ & $0.24 * *$ & $0.22^{* *}$ & $0.54^{* *}$ \\
\hline
\end{tabular}

* $\mathrm{p}<0.05 ;{ }^{* *} \mathrm{p}<0.01$

Legend: SE - Emotional Burden; IVP - Impact on Personal Life; SF - Financial Burden; RE- Reactions to Demands; PMEC - Perception of Efficacy and Control Mechanisms; SupF - Family Support; SPF- Satisfaction with Role and with the Relative; FF - Physical Function; DF - Physical Performance; DE - Emotional Performance; SG - General Health; Vita - Vitality; FS - Social Function; SM - Mental Health; Pain - Physical Pain; EADH - Scale of Anxiety and Clinical Depression.

Table 5 - Correlations of the dimensions of the SF 36 and of the EADH with the dimensions of the QASCI Short Version - Portugal, 2104

\begin{tabular}{|c|c|c|c|c|c|c|c|c|}
\hline & SE & IVP & SF & RE & PMEC & SupF & SPF & QASCI-VR \\
\hline \multicolumn{9}{|l|}{ SF 36} \\
\hline $\mathrm{FF}$ & $-0.23^{* *}$ & -0.04 & $-0.24 * *$ & $-0.11 *$ & $-0.21 * *$ & $-0.10^{*}$ & -0.03 & $-0.25^{* *}$ \\
\hline DF & $-0.36^{* *}$ & $-0.25^{* *}$ & $-0.27^{* *}$ & $-0.21 * *$ & $-0.30^{* *}$ & $-0.10^{*}$ & $0.14^{* *}$ & $-0.35^{* *}$ \\
\hline $\mathrm{DE}$ & $-0.28^{* *}$ & $-0.23^{* *}$ & $-0.21^{* *}$ & $-0.19 * *$ & $-0.17^{* *}$ & -0.03 & $0.11 *$ & $-0.25^{* *}$ \\
\hline SG & $-0.40^{* *}$ & $-0.19^{* *}$ & $-0.27^{* *}$ & $-0.27^{* *}$ & $-0.35^{* *}$ & $-0.10^{*}$ & -0.01 & $-0.42^{* *}$ \\
\hline Vita & $-0.38^{* *}$ & $-0.24^{* *}$ & $-0.24^{* *}$ & $-0.19^{* *}$ & $-0.31^{* *}$ & $-0.24^{* *}$ & $-0.17^{* *}$ & $-0.47^{* *}$ \\
\hline FS & $-0.34^{* *}$ & $-0.35^{* *}$ & $-0.27^{* *}$ & $-0.34^{* *}$ & $-0.37^{* *}$ & $-0.11^{*}$ & $0.10^{*}$ & $-0.43^{* *}$ \\
\hline SM & $-0.41^{* *}$ & $-0.33^{* *}$ & $-0.28^{* *}$ & $-0.33^{* *}$ & $-0.25^{* *}$ & $-0.16^{* *}$ & -0.04 & $-0.47^{* *}$ \\
\hline Pain & $-0.29^{* *}$ & $-0.18^{* *}$ & $-0.30^{* *}$ & $-0.15^{* *}$ & $-0.13^{* *}$ & -0.06 & 0.02 & $-0.29^{* *}$ \\
\hline \multicolumn{9}{|c|}{ EADH } \\
\hline EA & $0.44^{* *}$ & $0.33^{* *}$ & $0.31^{* *}$ & $0.32^{* *}$ & $0.35^{* *}$ & $0.22^{* *}$ & 0.04 & $0.51^{* *}$ \\
\hline $\mathrm{ED}$ & $0.43^{* *}$ & $0.30^{* *}$ & $0.28^{* *}$ & $0.26^{* *}$ & $0.42^{* *}$ & $0.24^{* *}$ & $0.13^{*}$ & $0.52^{* *}$ \\
\hline
\end{tabular}

${ }^{*} \underline{\mathrm{p}}<0.05 ; *$ $\mathrm{p}<0.01$

Legend: SE - Emotional Burden; IVP- Impact on Personal Life; SF - Financial Burden; RE - Reactions to Demands; PMEC - Perception of Efficacy and Control Mechanisms; SupF- Family Support; SPF - Satisfaction with Role and with the Relative; FF - Physical Function; DF - Physical Performance; DE - Emotional Performance; SG - General Health; Vita - Vitality; FS - Social Function; SM - Mental Health; Pain - Physical Pain; EADH - Scale of Anxiety and Clinical Depression.

With recourse to the AFC, the describe model (Figure 1), including 7 latent variables and 14 variables observed in Sample $2(\mathrm{n}=419)$ was tested. The indices showed a good adjustment to the model: $\mathrm{X}^{2} /(56)=102,982 ; \mathrm{p}=0,0001$;
$\mathrm{X}^{2} \mathrm{df}=1,839 ; \mathrm{CFI}=0,972 ; \mathrm{PCFI}=0,598 ; \mathrm{GFI}=0,966$; PG$\mathrm{FI}=0,515$; RMSEA $=0,045$ (IC90\%=0,031-0,058). All of the factor loads between the latent and observed variables were statistically significant. 


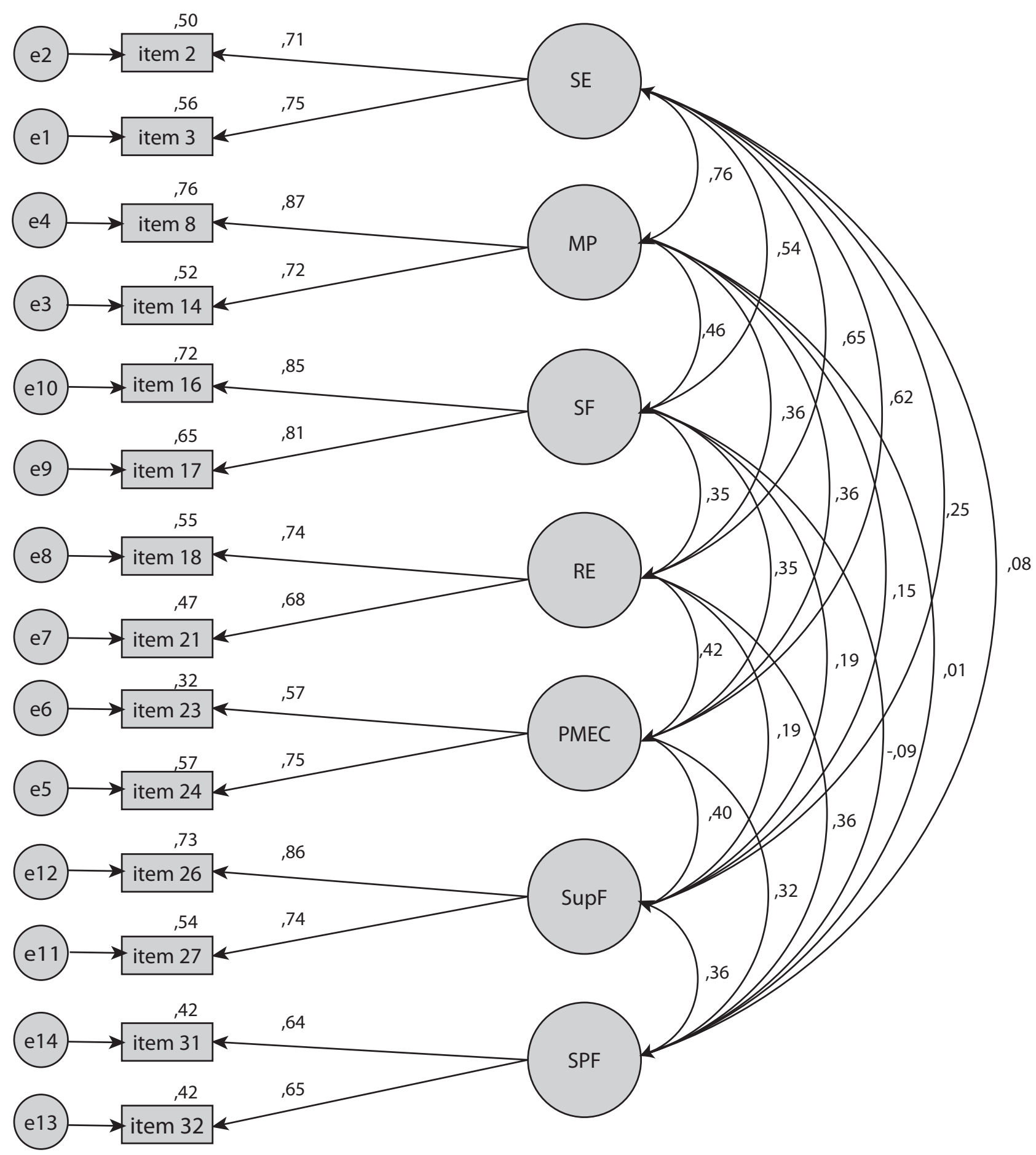

Figure 1 - Heptadimensional structure of the QASCI-VR. - Portugal, 2104

$X 2(56)=102,982 ; p=, 000 ; \times 2 d f=1,839$

$\mathrm{CFI}=$,972; $\mathrm{PCFI}=, 598 ; \mathrm{GFI}=, 966 ; \mathrm{PGFI}=, 515$

RMSEA $=, 045 ; \mathrm{P}($ rmsea $<=0.05)=, 723 ; \mathrm{IC} 90 \%], 031 ; 058[$

Legend: SE - Emotional Burden; IVP - Impact on Personal Life;

SF - Financial Burden; RE- Reactions to Demands;

PMEC - Perception of Efficacy and Control Mechanisms;

SupF - Family Support; SPF- Satisfaction with Role and with the Relative;

\section{DISCUSSION}

Despite the absence of consensus regarding the most appropriate procedures for the creation of shorter versions, recommendations exist ${ }^{(17-19)}$ and the application of clini- metric and psychometric procedures is suggested ${ }^{(18-20)}$. A previous study using two different methodologies for the creation of a Short Version of the QASCI was carried out 
by one of the authors, who defended the proposal presented here.

We sought to follow the recommendations of a study ${ }^{(18)}$, in using criteria for the reduction of items referring to the evaluation of the internal and external quality of the item, as well as the qualitative judgment of the measure. Of the set of criteria adopted for the reduction of items, the one which weighed the most on the choice was the factor load. In developing a review of the literature on methods used in 91 studies for creating reduced measures, the authors ${ }^{(19)}$ highlight that factor analysis is a popular technique, having been used in over half of the analyzed studies.

The adopted procedures resulted in a Short Version with two items per dimension. This criterion was used in other studies ${ }^{(6,14,21-22)}$. Despite the recommendation of a research study ${ }^{(23)}$ on the inclusion of at least three items per factor, we opted for a more parsimonious solution, given that the original instrument had seven dimensions, of which two presented only two items, with the options taken allowing is to ensure a structurally balanced measure. We also intended to ensure the theoretical model of the long version in preserving the heptadimensional structure.

All in all, the short version presented eight items which evaluate negative aspects and six, positive aspects. For the calculation of the global burden, the items of the positive dimensions must be inverted. The short version ensures greater representativeness of items which evaluate positive aspects of care than the long version, which corresponds to a challenge by several authors who argue for the need to evaluate such aspects ${ }^{(1)}$. The questioning of the positive aspects contributed to greater awareness and appreciation.

The developed instrument presented an internal consistency value assessed using Cronbach's alpha coefficient of 0.71 for the global scale and between 0.59 and 0.82 in the dimensions. Values exceeding 0.70 recommendable for ensuring the internal consistency of a measure ${ }^{(7,24)}$ and values exceeding 0.65 for each dimension ${ }^{(25)}$. Only the dimension
Satisfaction with role and with the relative failed to comply with this criterion.

It appears prudent not to adopt the preferential choice of items by the internal consistency value. Many authors criticize the valuation of internal consistency in the creation of reduced measures, alleging that it contributes to structurally fragile measures, with limited constructs and validity problems ${ }^{(18-19)}$. In the development of a reduced measure, the central focus to be studied must be more validity than fidelity ${ }^{(26)}$. The results encountered through negative and statistically significant correlations between the dimensions of the QASCI-VR and the dimensions of the SF 36 allow a judgment of its divergent validity. The correlation pattern encountered between the long version and the SF36 is similar to that described by the authors in the initial validation study. The positive correlations encountered with anxiety and in particular, with depression, attest to the convergent validity of the QASCI-VR, with values having been found close to those verified with the use of the long version. The correlation of 0.95 found between the long and short versions show that there is overlap between the results obtained by the application of both and is a significant contribution to its validation.

The results obtained by AFC, in an independent sample, confirm a good adjustment of the measure ${ }^{(10,16)}$. This technique is particularly appropriate since it permits the testing of whether the theoretical model is maintained intact after the removal of several items ${ }^{(19)}$.

\section{CONCLUSION}

The Short Version of the QASCI showed itself to be structurally balanced, ensuring fidelity, validity of construct and factor validity in the evaluation of the burden of the caregiver. Studies are nevertheless desirable which confirmed the evaluated proprieties, and which complete other psychometric properties, namely temporal stability and the responsiveness of the short instrument, so that it confers greater robustness to its clinical application.

\section{RESUMO}

Objetivo: Criar uma versão reduzida do Questionário de Avaliação da Sobrecarga do Cuidador Informal (QASCI), que seja estruturalmente equivalente e que reúna critérios de fidelidade e validade. Método: Através de dados secundários a estudos anteriores constituíram-se duas amostras, uma para o desenvolvimento da versão reduzida e a segunda para estudar a validade fatorial. Os participantes responderam ao QASCI, ao SF 36, à EADH e a perguntas sociodemográficas. Resultados: A versão reduzida de 14 itens mostrou adequadas propriedades psicométricas de validade e consistência interna adaptada a uma estrutura heptadimensional que avalia aspetos negativos e positivos do cuidar. Conclusão: A análise fatorial confirmatória revelou um bom ajustamento ao modelo teórico preconizado.

\section{DESCRITORES}

Cuidadores; Família; Estudos de Validação; Psicometria.

\section{RESUMEN}

Objetivo: Crear una versión reducida del Cuestionario de Evaluación de la Sobrecarga del Cuidador Informal (CESCI) que sea estructuralmente equivalente y que reúna criterios de fidelidad y validez. Método: Mediante datos secundarios a estudios anteriores se constituyeron dos muestras, la primera para el desarrollo de la versión reducida y la segunda para estudiar la validez factorial. Los participantes respondieron al CESCI, el SF 36, la HAD y a preguntas sociodemográficas. Resultados: La versión reducida de 14 ítems demostró adecuadas propiedades psicométricas de validez y consistencia interna adaptadas a una estructura heptadimensional que evalúa los aspectos negativos y positivos del cuidar. Conclusión: El análisis factorial confirmatorio reveló un buen ajuste al modelo teórico preconizado.

\section{DESCRIPTORES}

Cuidadores; Familia; Estudios de Validación; Psicometría. 


\section{REFERENCES}

1. Martins T. Acidente vascular cerebral: qualidade de vida e bem-estar dos doentes e familiares cuidadores. Coimbra: Formasau; 2006.

2. Martins T, Ribeiro JP, Garrett C. Estudo de validação do questionário de avaliação da sobrecarga para cuidadores informais. Psic Saúde Doenças. 2003;4(1):131-48.

3. Martins T, Ribeiro JP, Garrett C. Questionário de Avaliação do Cuidador Informal (QASCI): reavaliação das propiedades psicométricas. Referência. 2004;(11):17-31.

4. Chou P, Rau KM, Lin CC. Development and psychometric testing of a short version of the Barriers Questionnaire-Taiwan form for cancer patients. Int J Nurs Stud. 2011;48(9):1071-9.

5. Kimura M, Carandina DM. Development and validation of a short form instrument for the evaluation of Quality of Working Life of nurses in hospitals. Rev Esc EnfermUSP [Internet]. 2009[cited 2013 July 20];43(n.spe):1044-54. Available from: http://www.scielo.br/pdf/reeusp/ v43nspe/en_a08v43ns.pdf

6. Raes F, Pommier E, Neff KD, Van Gucht D. Construction and factorial validation of a short form of the Self-Compassion Scale. Clin Psychol Psychother. 2011;18(3):250-5.

7. Ribeiro JLP. Metodologia de investigação em psicologia e saúde. $3^{a}$ ed. Porto: Legis; 2010.

8. Ware JE Jr, Sherbourne CD. The MOS 36-item short form health survey (SF36). I. Conceptual framewook and item selection. Med Care. 1992;30(6):473-83.

9. Zigmond AS, Snaith RP. The hospital anxiety and depression scale. Acta Psychiatr Scand. 1983;67(6):361-70.

10. Kline RB. Principles and practice of structural equation modeling. $3^{\text {rd }}$ ed. New York: Guilford; 2010.

11. Hair JJF Jr, Black WC, Babin BJ, Anderson RE, Tatham RL. Análise multivariada de dados. 6ª ed. Porto Alegre: Bokman; 2009.

12. Gouveia V, Santos W, Pimentel C, Diniz PKC, Fonseca PN. Questionário de comportamentos anti-sociais e delitos: evidencias psicométricas de uma versão reduzida. Psicol Reflex Crit. 2009;22(1):20-8.

13. Jacobs JE, Maillé AR, Akkermans RP, van Weel C, Grol RP. Assessing the quality of life of adults with chronic respiratory diseases in routine primary care: construction and first validation of the 10-Item Respiratory Illness questionnaire-monitoring 10 (RIQ-MON 10). Qual Life Res. 2004;13(6):1117-27.

14. Stöber J, Joormann J. A short form of the Worry Domains Questionnaire: construction and factorial validation. Pers Indiv Differ. 2001;31(4):591-8.

15. Li H, Lopez V. Development and validation of a short form of the Chinese version of the State Anxiety Scale for Children. Int J Nurs Stud. 2007;44(4):566-73.

16. Maroco J. Análise de equações estruturais: fundamentos teóricos, software \& aplicações. Pêro Pinheiro: ReportNumber; 2010.

17. Coste J, Guillemin F, Pouchot J, Fermanian J. Methodological approaches to shortening composite measurement scales. J Clin Epidemiol. $1997 ; 50(3): 247-52$.

18. Stanton JM, Sinar EF, Balzer WK, Smith PC. Issues and strategies for reducing the length os self-report scales. Pers Psychol. 2002;55(1):16794.

19. Goetz C, Coste J, Lemetayer F, Rat AC, Montel S, Recchia S, et al. Item reduction based on rigorous methodological guidelines is necessary to maintain validity when shortening composite measurements. J Clin Epidemiol. 2013;66(7):710-8.

20. Juniper EF, Guyatt GH, Streiner DL, King DR. Clinical impact versus factor analysis for quality of life questionnaire construction. J Clin Epidemiol. 1997;50(3):233-8.

21. Blozik E, Kochen MM, Herrmann-Lingen C, Scherer M. Development of a short version of the Neck Pain Disability Scale. Eur J Pain. 2010;14(8):864.e1-7.

22. Garnefski N, Kraaij V. Cognitive emotion regulation questionnaire: development of a short 18-item version (CERQ-short). Pers Individ Differ. 2006;41(6):1045-53

23. Raubenheimer J. An item selection procedure to maximise scale reability and validity. J Ind Psychol. 2004;30(4):59-64.

24. Field A. Discovering statistics using SPSS. 2nd ed. London: Sage; 2005.

25. Beaton DE, Wright JG, Katz JN; Upper Extremity Collaborative Group. Development of the Quick DASH: comparison of three itemreduction approaches. J Bone Joint Surg Am. 2005;87(5):1038-46.

26. Widaman K, Little T, Preacher K, Sawalani G. On creating and using short forms of scales in secondary research. In: Kali T, Donnellan MB, Lucas RE, editors. Secondary data analysis: an introduction for psychologists.Washington: APA; 2011. p. 39-61. 


\section{APPENDIX 1}

QASCI Short Version - Portugal, 2014

\begin{tabular}{|c|c|c|c|c|c|}
\hline \multirow{2}{*}{ Nas últimas 4 semanas } & Não/nunca & Raramente & Às vezes & Quase sempre & Sempre \\
\hline & 1 & 2 & 3 & 4 & 5 \\
\hline $\begin{array}{l}\text { 1. Considera que, tomar conta do seu familiar, é psicologicamente } \\
\text { difícil? }\end{array}$ & $\mathrm{O}$ & O & O & $\mathrm{O}$ & $\mathrm{O}$ \\
\hline 2.Sente-se cansada(o) e esgotada(o) por estar a cuidar do seu familiar? & O & O & O & O & O \\
\hline $\begin{array}{l}\text { 3. Os planos que tinha feito para esta fase da vida têm sido altera- } \\
\text { dos em virtude de estar a tomar conta do seu familiar? }\end{array}$ & $\mathrm{O}$ & O & O & $\mathrm{O}$ & $\mathrm{O}$ \\
\hline $\begin{array}{l}\text { 4. A sua vida social, (p. ex., férias, conviver com familiares e ami- } \\
\text { gos) tem sido prejudicada por estar a cuidar do seu familiar? }\end{array}$ & O & O & O & $\mathrm{O}$ & O \\
\hline $\begin{array}{l}\text { 5. Tem sentido dificuldades económicas por estar a tomar conta do } \\
\text { seu familiar? }\end{array}$ & O & O & O & $\mathrm{O}$ & $\mathrm{O}$ \\
\hline $\begin{array}{l}\text { 6. Sente que o seu futuro económico é incerto, por estar a cuidar } \\
\text { do seu familiar? }\end{array}$ & $\mathrm{O}$ & O & O & O & $\mathrm{O}$ \\
\hline $\begin{array}{l}\text { 7.Já se sentiu ofendida(o) e zangada(o) com o comportamento do } \\
\text { seu familiar? }\end{array}$ & O & O & O & O & O \\
\hline 8.Sente-se manipulada(o) pelo seu familiar? & O & O & O & O & O \\
\hline $\begin{array}{l}\text { 9. Consegue fazer a maioria das coisas de que necessita, apesar do } \\
\text { tempo que gasta a tomar conta do seu familiar? }\end{array}$ & $\mathrm{O}$ & O & O & $\mathrm{O}$ & $\mathrm{O}$ \\
\hline $\begin{array}{l}\text { 10. Sente-se com capacidade para continuar a tomar conta do seu } \\
\text { familiar por muito mais tempo? }\end{array}$ & O & O & O & O & $\mathrm{O}$ \\
\hline $\begin{array}{l}\text { 11. A família (que não vive consigo) reconhece o trabalho que tem, } \\
\text { em cuidar do seu familiar? }\end{array}$ & O & O & O & O & O \\
\hline 22. Sente-se apoiada(o) pelos seus familiares? & O & O & O & O & $\mathrm{O}$ \\
\hline 33. Sente-se mais próxima(o) do seu familiar por estar a cuidar dele? & O & O & O & $\mathrm{O}$ & $\mathrm{O}$ \\
\hline $\begin{array}{l}\text { 14. Cuidar do seu familiar tem vindo a aumentar a sua auto-estima, } \\
\text { fazendo-a(o) sentir-se uma pessoa especial, com mais valor? }\end{array}$ & O & O & O & $\mathrm{O}$ & O \\
\hline
\end{tabular}

